(Reprinted from Nature, Vol. 273, No. 5657, pp. 45-49, May 4, 1978)

(c) Macmillan Journals Ltd., 1978

\section{Sampling and observation of oceanic mantle and crust on Gorringe Bank}

- THF structure and nature of the uppermost oceanic mantle and crust has been, and still is, the subject of a major international research effort'. Yet the direct field evidence known to us on this subject, whether obtained by drilling in the I.P.O.D. Oceanic crust programme ${ }^{2}$ or by submersible surveying in the Famous programme ${ }^{3}$, has been either very incomplete or limited to the upper part of layer 2. As a result, the problem of the comparison between ophiolites and oceanic crust is still debated'. We report here the preliminary results of an in silu geological survey in which we have sampled and observed what we believe to be an almost complete geological section starting a few kilometres below the Moho discontinuity and ending in the upper part of layer 2 (ref. 4). This section outcrops on the flanks of Gorringe Bank, which is a ridge $200 \mathrm{~km}$ long and $60 \mathrm{~km}$ wide between Tagus and Horseshoe abyssal plains in the Atlantic ocean, South West of Cape Saint Vincent, Portugal (Fig. 1). -
Gorringe Bank lies on the northern boundary of the seismic belt which defines the Africa-Europe plate boundary' between the Açores triple junction and Gibraltar. In the area of Gorringe Bank, the Africa plate is presently underthrusting the Europe plate in a souih-south-east-northnorth-west direction'. A very large, 350 mgal, gravimetry free-air anomaly is associated with the Bank. whereas the seismic belt to the south-east is characterised by a $-80 \mathrm{mgal}$ negative anomaly ${ }^{6,7}$. Le Pichon et al. ${ }^{7}$ described the structure associated with this seismic belt as 'an incipient trench between two oceanic plates' colliding at a relatively slow rate. Gorringe Bank was assumed by them to be a piece of oceanic crust uplifted at the time. of formation of the trench. 5-10 Myr ago. This interpretation led to the implantation of hole 120 of the DV Glomar Challenger which indicated the presence of Barremian (115 Myr) sediments lying directly over oceanic basement and suggested the existence of a significant amount of uplift (several kilometres) during the Miocene ${ }^{2-10}$. The hypothesis of Gorringe Bank as a piece of oceanic crust uplifted and slightly tilted in Neogene time together with its original sedimentary cover was widely adopted ${ }^{8-11}$. It was further

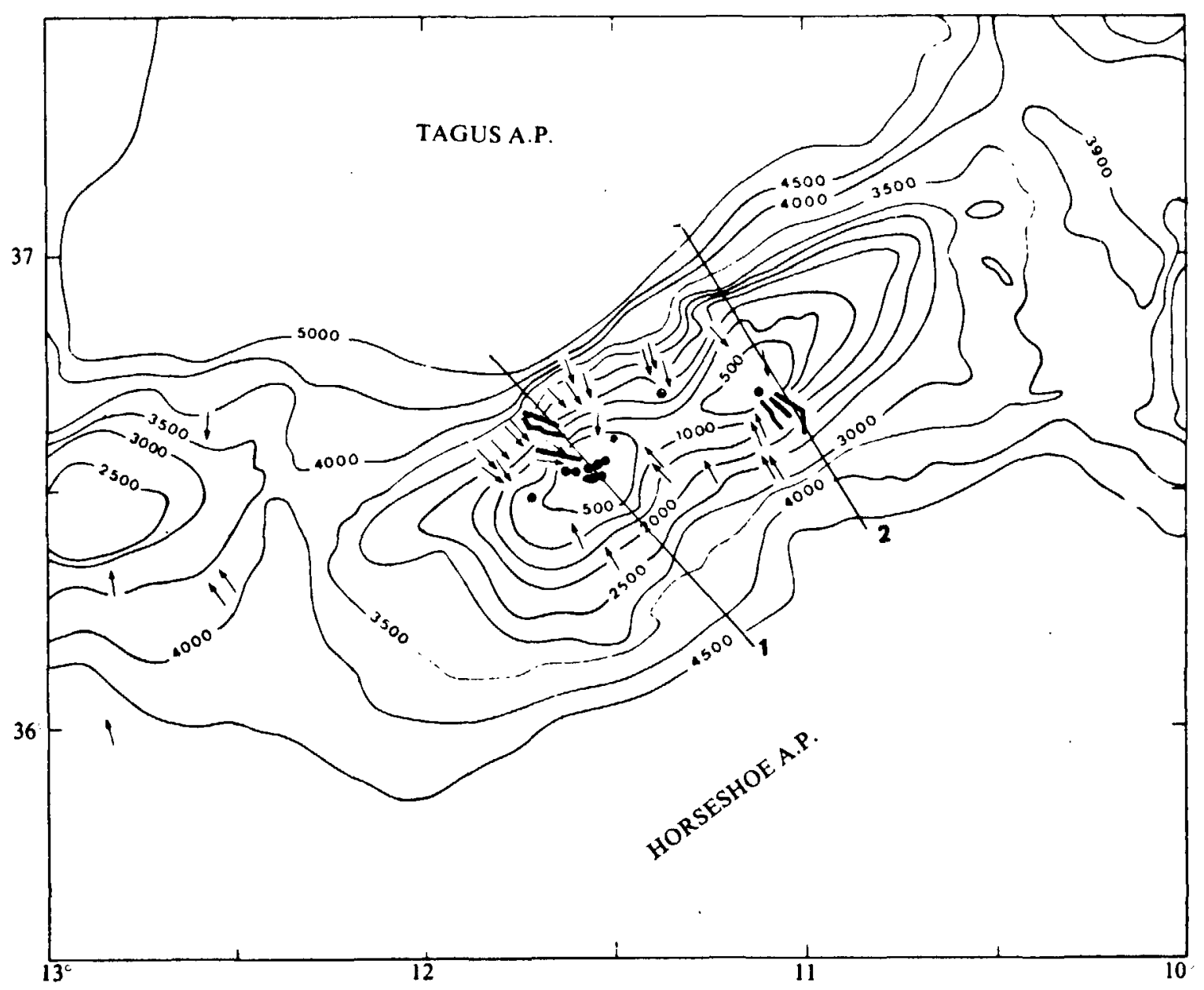

Fig. 1 Location of dives and sample sites on Gorringe Bank. (1) and (2) are bathymetric profiles shown on Figs 3 and 4. Heavy lines, zones surveyed by submersible dives; $\bullet$, core; $\rightarrow$ dredge. 
pointed out that the age of the sedimentary cover agreed with the assumed age of opening between Iberia and North America ${ }^{12}$.

Since then, however, a large amount of oceanographic work has suggested the importance of the Mesozoic and Palaeogene complex evolution of the Africa-Iberia plate boundary ${ }^{13-17}$ and showed that the transform motion has been prevalent during a great part of its history. It thus seemed reasonable to associate Gorringe Bank with a palaeotransform fault with which it had many structural and petrological similarities (refs $8-10,16,18, \mathrm{~J}$. Cann, personal communication). In this interpretation, Gorringe Bank would be a diapir emplaced at an initial time along the Transform Fault (see ref. 19). A geological field survey of Corringe Bank's flanks with the submersible Cyana of the Centre National pour l'Exploitation des Océans was made in August 1977 to test the validity of these interpretations.

Gorringe Bank lies in a south-west-north-east direction between the Tagus Abyssal Plain to the north and the Horseshoe Abyssal Plain to the south (Fig. 1). It is $250 \mathrm{~km}$ long and $100 \mathrm{~km}$ wide. Its southern flank has a thick sedimentary cover whereas the northern flank is steeper with widespread large-scale slumping and consequent outcropping of the acoustic basement. The basement also outcrops near the summit where it picrces the sedimentary cover, forming two massifs which culminate at $25 \mathrm{~m}$ water depth. Gettysburg to the south-west and Ormonde to the northeast.

Two in situ geological sections have been obtained. The first starts at a water depth of $2,600 \mathrm{~m}$ on the northern flank and ends on the summit of Gettysburg. Twenty-two successful sampling stations were made during four submersible dives along this north-west-south-east section. In addition, orientated samples were obtained on the summit $(2540 \mathrm{~m})$ by skin-diving. The second section starts at a depth of $1.800 \mathrm{~m}$ on the southern flank and ends on the edge of Ormonde at $200 \mathrm{~m}$. Twelve sampling stations were made during three dives along this south-east-north-west section (Fig. 1).

On the basis of dredges in the area (Noratlante, Nestlante and Gibraco cruises of CNEXO, and J. Cann, personal communication), we had assumed that Gettysburg was essentially made of sepentinite. This was confirmed by the first profile (Fig. 2) which demonstrates that the serpentinites form a major part of outcrops and keep a remarkable structural and chemical homogeneity from top to bottom.
These are former harzburgites, with a north-south banded structure dipping at $20^{\circ}$ to the East. Evidence of high temperature plastic flow is present in most specimens. The orientated samples obtained on the summit by skin-diving show a foliation. due to high temperature plastic flow, with a similar orientation. A $200 \mathrm{~m}$ high cliff, made up of microlitic dolerites, at a depth of $1,250 \mathrm{~m}$, corresponds either to a sill or rather to a thick flow. Dredgings had already shown the existence of a Cainozoic volcanic activity of this type". The serpentinites are widely covered by recent mud and by consolidated sediments of Cenozoic and Lower Cretaceous (Barramo-Aptian) age. Barremo-Aptian was also the age obtaincd by the Glomar Challenger for the sediments lying immediately above the basement.

The slope is also covered with serpentinite blocks and pebhles. Breccias made up of serpentinite blocks in a detrital calcareous matrix outcrop on steep scarps on the slope (Fig. 2). We believe that they are not due to tectonic activity of diapiric or faulting type as listric surfaces have not been observed. They are probably the result of slope rubble consolidation. Listric surfaces have been observed in massive serpentinite along nearly vertical fault planes with variable directions.

Thus Gettysburg consists of massive structurally homogeneous serpentinite over a thickness of at least $2.6 \mathrm{~km}$. $\therefore$ ith no indication of diapiric activity, suggesting that it is a piece of mantle. Because of the frequent presence of gabbros in the dredging made over Ormonde, we had assumed that it might correspond to a piece of oceanic crust, the $20^{\circ}$ tilting to the East accounting for the dissymmetry between Ormonde and Gettysburg. This was verified by the three dives made on the southern slope of Ormonde.

Figure 3 shows that between 1,600 and $8(x) \mathrm{m}$, the slope consists of a monotonous rise covered with mud, with a few scarps made up of neogene limestones and conglomerates with volcanic pebbles. There is, however, a thick outcrop of volcanic breccias near $1.000 \mathrm{~m}$. Between 800 and $4.50 \mathrm{~m}$ there are high cliffs made up of apparently fresh gabbros having an irregular structure with finer grain zones alternating with 'pegmatoidal' zones. They have a vague orientation with a $20^{\circ}$ dip to the east or north-east. This orientation is apparently tectonic as bands of highly foliated gabbros cut the massive gabbros along the same orientation. Six hands, from one to a few metres thick, have been observed over $60 \mathrm{~m}$ of cliffs in gabbro. Towards the top, doleritic dykes become more and more numerous.

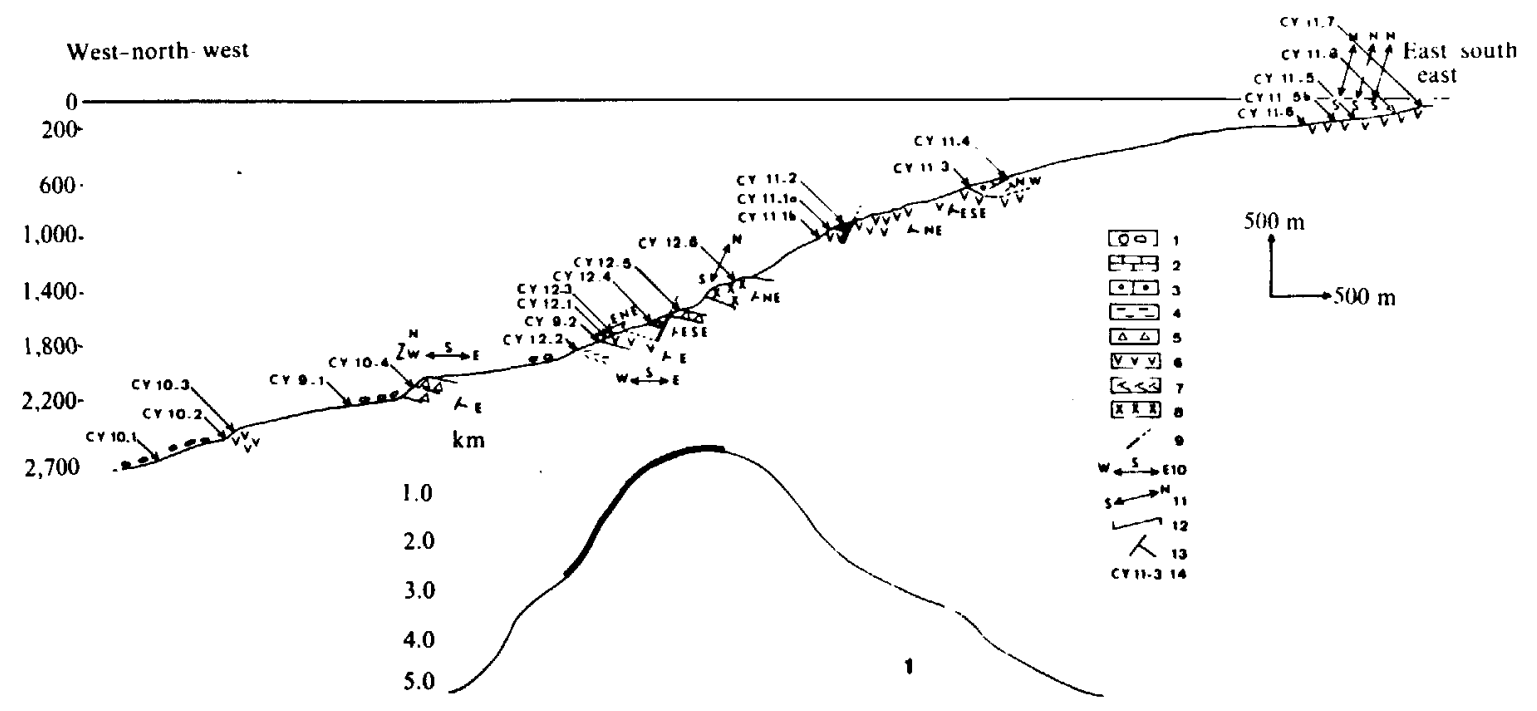

Fig. 2 Synthetic section of the north-west flank of Gettysburg seamount. Dives 8, 9, 10, 11, 12. 1, isolated blocks: 2. limestones; 3, conglomerate; 4, Albo-Aptian marls; 5 , serpentinites breccias; 6 , serpentinites; 7, microlitic lavas; 8 , dolerites; 9 , fault ; 10 , schistosity lineation; 11 , fracture trends; 12, horizontal movement; 13, bedding dip; 14, samples collected during dives. 


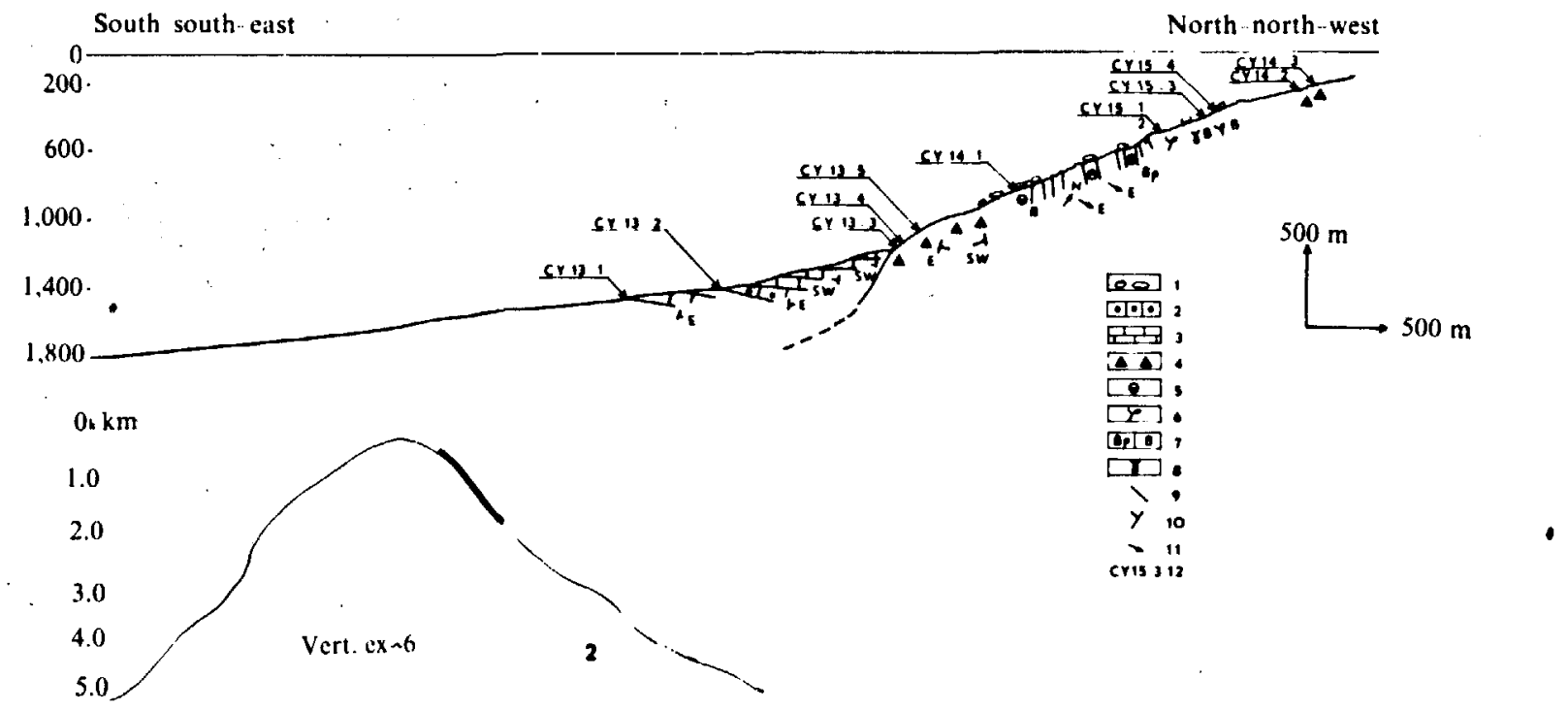

Fig. 3 Synthetic profile of the south-east flank of Ormonde seamount (dives 13, 14, 15). 1. isolated blocks: 2 , conglomerate: 3 limestones; 4 , volcanic breccia; 5 , gabbros; 6 , phonolites: 7 , basaltic pillow lavas and basalts: 8 . metagabbros: 9 , diabase dykes: 10, bedding dip: 11 , foliation lineation; 12, samples collected during dives.

Their orientation seems to be quite constant: north-south with a 70 to $90^{\circ}$ dip to the east ( 10 measurements). Near $450 \mathrm{~m}$. dykes are so numerous that the formation should be considered to be a dyke complex. The fine grained and greenish intruded rock might correspond to an altered basalt. It is at this level that apparently basaltic pillow-lavas have been observed in the rubble. The section ends near $200 \mathrm{~m}$ on the edge of Ormonde plateau in trachytic and phonolitic very fresh explosion breccias. These breccias are most probably related to the Cainozoic acid volcanism'".

Gorringe Bank is independent of the Iberian continental margin and is situated in an oceanic environment between Tagus and Horseshoe Abyssal Plains (5,000 m depth) $)^{6,11,14,16}$. The preceding descriptions present numerous affinities with an ophiolitic complex in which Gettysburg is at its base (serpentinites with a tectonite structure) and Ormonde at its top (Fig. 4). However, we have not observed the chromite dunites and the gabbroï cumulates expected in the intermediate section which may lie below $800 \mathrm{~m}$ in Ormonde. Similarly, we cannot prove that the dykes and the pillow lavas near the edge of Ormonde plateau are basaltic. They might be due to the Cenozoilc acid volcanism. In spite of these reservations, we conclude that Gorringe Bank is a piece of oceanic crust and that the interpretation which assimilates an ophiolitic complex to a fragment of oceanic mantle and crust has been justified in the field.

Another conclusion of these observations is that the structure seems not to be disturbed in a major way by faulting tectonics. A recent morphologic survey made before the dives suggests. however, that the bank is cut by north-north-east-south-south-west faults with probably a left-lateral component of motion. We still do not have enough information to date the events after the formation of this fragment of oceanic crust. We simply note that the oldest sediments (Barremo-Aptian) obtained using a submersible have the same age as those obtained by drilling. and apparently lie directly on top of the serpentinites on the west. whereas they lie on top of gabbros and ultrabasics at the drilling site. This suggests. but does not prove conclusively. that the ultrabasics were already outcropping in Barremo-Aptian time. In this case the tilting of Gorringe Bank could be linked to the development of the very large ridge corresponding to $\mathrm{J}$ anomaly $(110 \mathrm{Myr} \text { Aptian })^{2}$ or with the initiation of spreading at the Jurassic-Cretaceous boundary. The survey has also confirmed the importance of an acid volcanic phase that can be linked with Cenozoïc tectonism ${ }^{25,17}$

Thus, the Gorringe Bank would be the result of an uplift of about $10 \mathrm{~km}$ of the mantle and overlying oceanic crust, due to a slight eastward tilt. We found no evidence of major deformations in the analysis of the structures of serpentinites and sediments. The zones of highly tectonised gabbros correspond to horizontal thrusts within the oceanic crust. They provide direct evidence for the existence in the oceanic crust of an important thrusting in various metamorphic conditions. This hypothesis has been proposed for our recent studies in ophiclites ${ }^{21,22}$. In this interpretation. the saddle between Gettysburg and Ormonde (Fig. 1) would correspond to the deeper part of the oceanic crust. Alternatively. the general structure might be explained by a

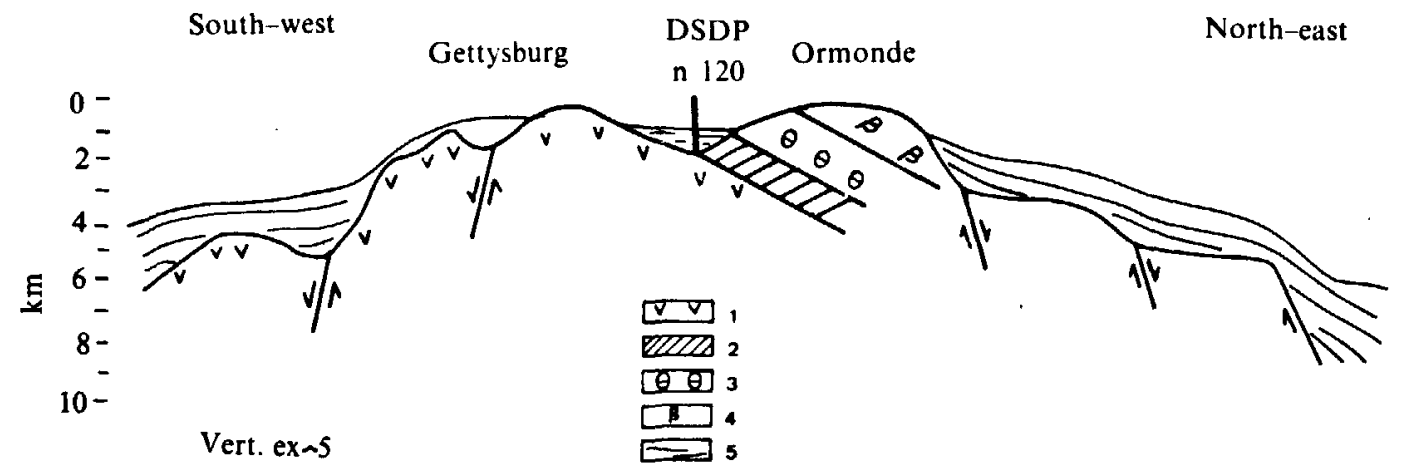

Fig. 4 Interpretative longitudinal section of Getlysburg and Ormonde seamounts. The sequence of the various layers is shown. 1, Serpentinites: 2 , intermediate bodies 3, gabbros; 4, basalts

5 , sedimentary layers. 
downward movement to the east of the fault suggested by the morphology between the two massifs.

From our results it seems that a nearly complete oceanic crust section and 4 to $5 \mathrm{~km}$ of underlying upper mantle are outcropping on the flanks of Gorringe Bank.

The conformity between the different basement layers and the lack of evidence of strong tectonic disturbance lead us to reject the hypothesis of a diapiric origin for the Gorringe Bank. Instead, we think that the present configuration of the Bank results from a gentle eastward tilt of the oceanic basement followed by vertical uplift. Also noteworthy is the fact that the surveyed section appears very similar to the standard section of an ophiolitic complex.

Cyagor cruise was organised by CNEXO under the initiative of the Comite pour les Programmes Submersibles. We thank J. Cann for communicating unpublished preliminary dredge descriptions, also the submersible team and the RV Suroit crew. Contribution 571 Departement Scientifique, Centre Oceanologique de Bretagne.

\section{Jean-Marie AuZende JEAN-LouIS Olivet}

Centre Océanologique de Bretagne,

B.P. 337, 29273 Brest cedex, France

\section{JACQUES CHARVET}

Laboratoire de Géologie Dynamique,

Université des Sciences et Techniques de Lille,

59650 Villeneuve d'Asq, France

\section{Alain Le Lann}

Université de Bretagne Occidentale,

Laboratoire d'Océanologie et de Géodynamique, 29283 Brest cedex, France

Xavier Le Pichon

CNEXO, 66 avenue d'léna,

75016 Paris, France

Jose Hyppolito Monteiro

Servico de Fomento Mineiro,

Arquivo de Amostras Castan Heira de Ribatejo, Portugal

Adolphe Nicolas

Laboratoire de Tectonophysique,

Université de Nantes,

B.P. 1044, 44037 Nantes cedex, France

\section{ANTONIO Ribeiro}

Service Géologique du Portugal. Lisbonne, Portugal
Received 23 January: accepted 13 February 1978.

1. Le Pichon. X. Nature 267.765 (1977).

Arcyana Science $190,108(1975)$

. Cyagor C.r.Acad. Sci. Paris 285, (1977)

5. Fukao, Y. Earth planet. Sci. Lett. 18, 20\$ (1972)

6. Purdy, G. A. Geophys.J. R. astr. Soc. 43, 973 (1975).

1. Le Pichon. X.. Bonnin, J. \& Pautot, G. The Gibraltar end of the Azores-Gibraltar

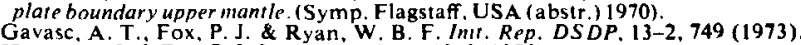

8. Gavasc. A. T. Fox, P. J. \& Ryan, W. B. F. Inir. Rep.

9. Honnorez. J. \& Fox. P. J. Init. Rep. DSDP 1 13-2(1972

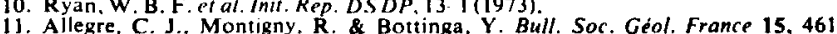
12. Hsu K J. \& Ryan. J W. B in Histoire Structurale du Galle de Gascogne. Technip) Paris VI 2 I VI 2.8(1971)

13. Olivet, J, L... Pastouret, L.. Auzende, J. M. \& Auffret. G. A. Armorican margin colution in relation with the Bay of Biscay Genesis (abstr.) (Coll. IUSGS Durham, 1976

14. Le Pichon. X.. Sibuet. J. C. \& Francheteau. J. Tectonophysics 3, 169 (1977) Feraud, G.. Bonnin. J.. Olivet, J. L.. Auzende, J. M. \& Bougault. H. C.r. Acad St. Paris 285, 1203 (1977).

16. Olivet, J. L. et al. Réunion Ann. Sci. Terre, Montpellier (abstr.) 408 (1975) Olivet, J. L., Bonnin, J. \& Auzende, J. M. (abstr.), 4 th Reunion Ann. Sci. Terre, Paris, 311 (1976)

18. Boillot, G. et al. Rev. Geogr. Phys. Geol. Dyn. 16, 1, 75 (1974).

9. Bonatt1. E. \& Honnorez, J. Srience 174. 1329 (1971).

20. Olivet, J. L. Seance Sper. Soc. Geol. Fr. (1977).

21. Girod. M. \& Caby 3rd Reun. Sci. Terre, Montpellier (abstr.) 167 (1975) 125 (1977). 